\title{
Erratum to: Chromatographic and chemical analysis of Sarcostemma viminale $\mathrm{R}$. Br.
}

\author{
A. S. Girme • R. D. Bhalke • S. A. Nirmal • M. J. Chavan
}

Published online: 19 August 2014

(C) Institute of Korean Medicine, Kyung Hee University and Springer Science+Business Media Dordrecht 2014

\section{Erratum to: Orient Pharm Exp Med}

\section{DOI: $10.1007 / \mathbf{s} 13596-014-0157-3$}

There are some changes in the order of structures and the structures themselves in page 5, under Results and discussion. Please find the corrected structures here.
Structures of the isolated compounds from collected data-<smiles>CCC(C)(C)CC</smiles><smiles>CCC(C)(C)C(C)(C)CC</smiles><smiles>C=CC(C)(C)CC</smiles><smiles>CCC(C)(C)CC</smilesSP-3(b)

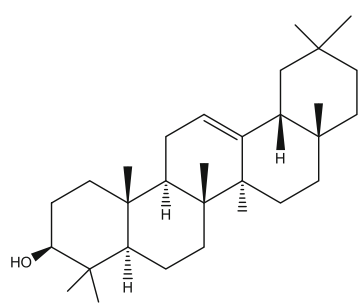

SP-4(a)<smiles>CCC(CC[C@H](C)[C@H]1CCC2C3CC=C4CC(O)CC[C@]4(C)C3CCC21C)C(C)C</smiles>

SP-5

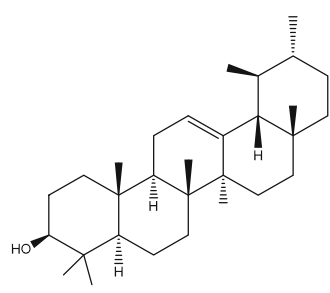

SP-4(b)<smiles>O=C(O)c1cc(O)c(O)c(O)c1</smiles>

SMEA-2

R. D. Bhalke

Department of Pharmacognosy, Sanjivani College of Pharmaceutical Education and Research, Kopargaon, MH 423603, India

\section{J. Chavan}

Department of Pharmacognosy, Amrutvahini College of Pharmacy, Sangamner, MH 422068, India

\section{A. S. Girme} Interdisciplinary School of Health Sciences, University of Pune, Pune, MH, India 